\title{
Canada, Libraries and \\ the Digital Economy
}

OLA Super Conference

Toronto February 12014

Catherine Middleton

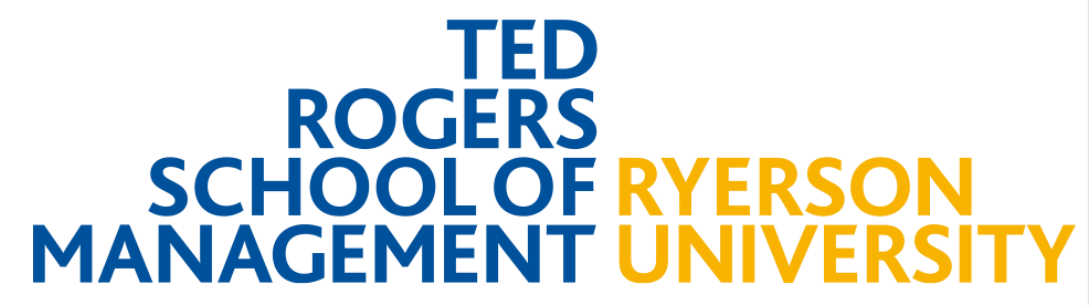




\section{What I will talk about}

- Digital economy strategies

- Canada's digital economy

- wired broadband networks

- mobile phones and broadband

- extending network availability, increasing quality

- Libraries as enablers of the digital economy 
Digital economy strategies 
See the end of this PDF for links to all documents and data cited in the presentation.

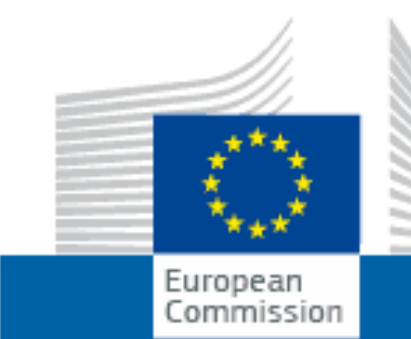
European
Commission

\section{DIGITAL AGENDA FOR EUROPE}

\section{A Europe 2020 Initiative}

European Commission > Digital Agenda for Europe

\section{LIVING THE IN2015 VISION

Singapore has made good progress in implementing the Intelligent Nation (iN2015) Masterplan. We have established a highly connected nation with a globally competitive infocomm industry, infocomm-savvy workforce and spearheaded the transformation of key economic sectors, government and society.
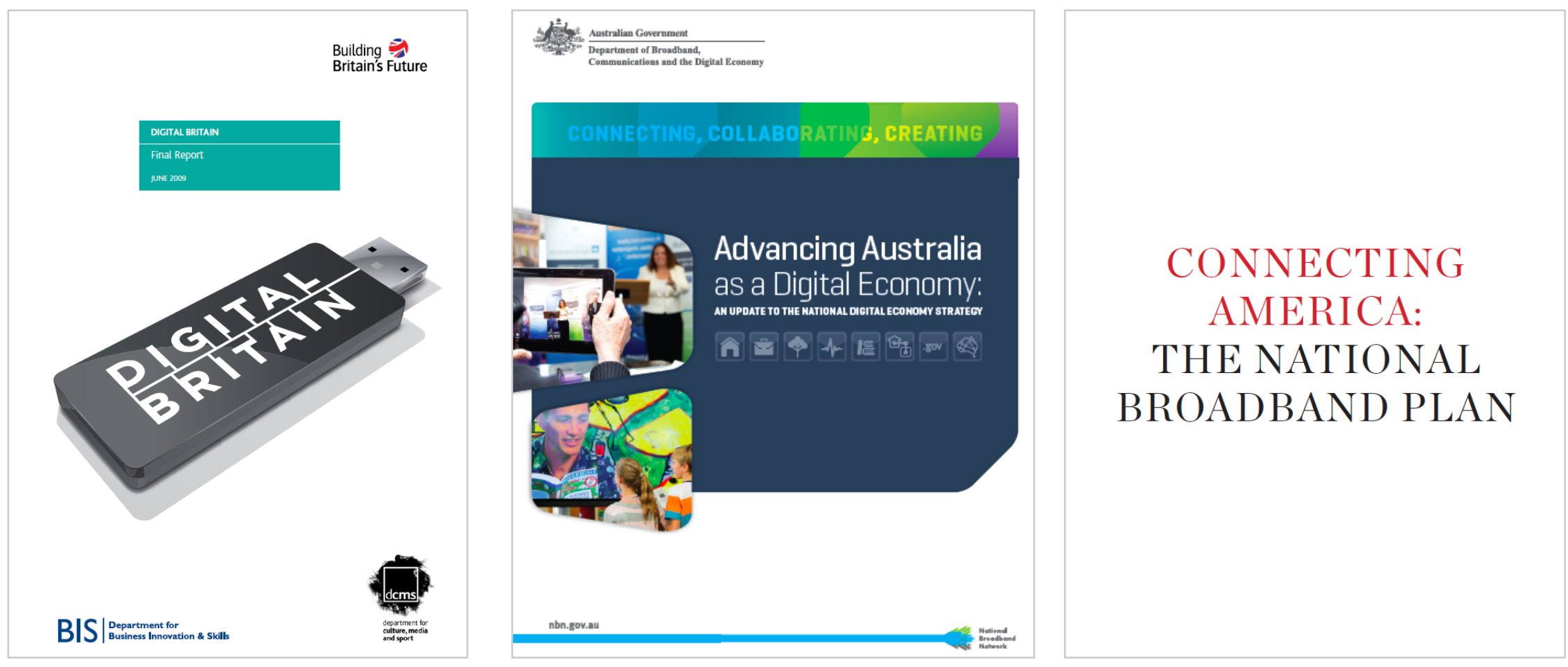


\section{What do digital strategies do?}

- Set targets and plan for roll out of high quality broadband infrastructure

- e.g. all Europeans to have access to broadband networks $\geq 30 \mathrm{Mbps}$ by 2020 and $50 \%$ of EU households adopting services with speeds of $100 \mathrm{Mbps}$ or greater by 2020

- 100 million U.S. homes should have affordable access to actual download speeds of at least 100 Mbps and actual upload speeds of at least 50 Mbps by 2020 


\section{National broadband infrastructure}
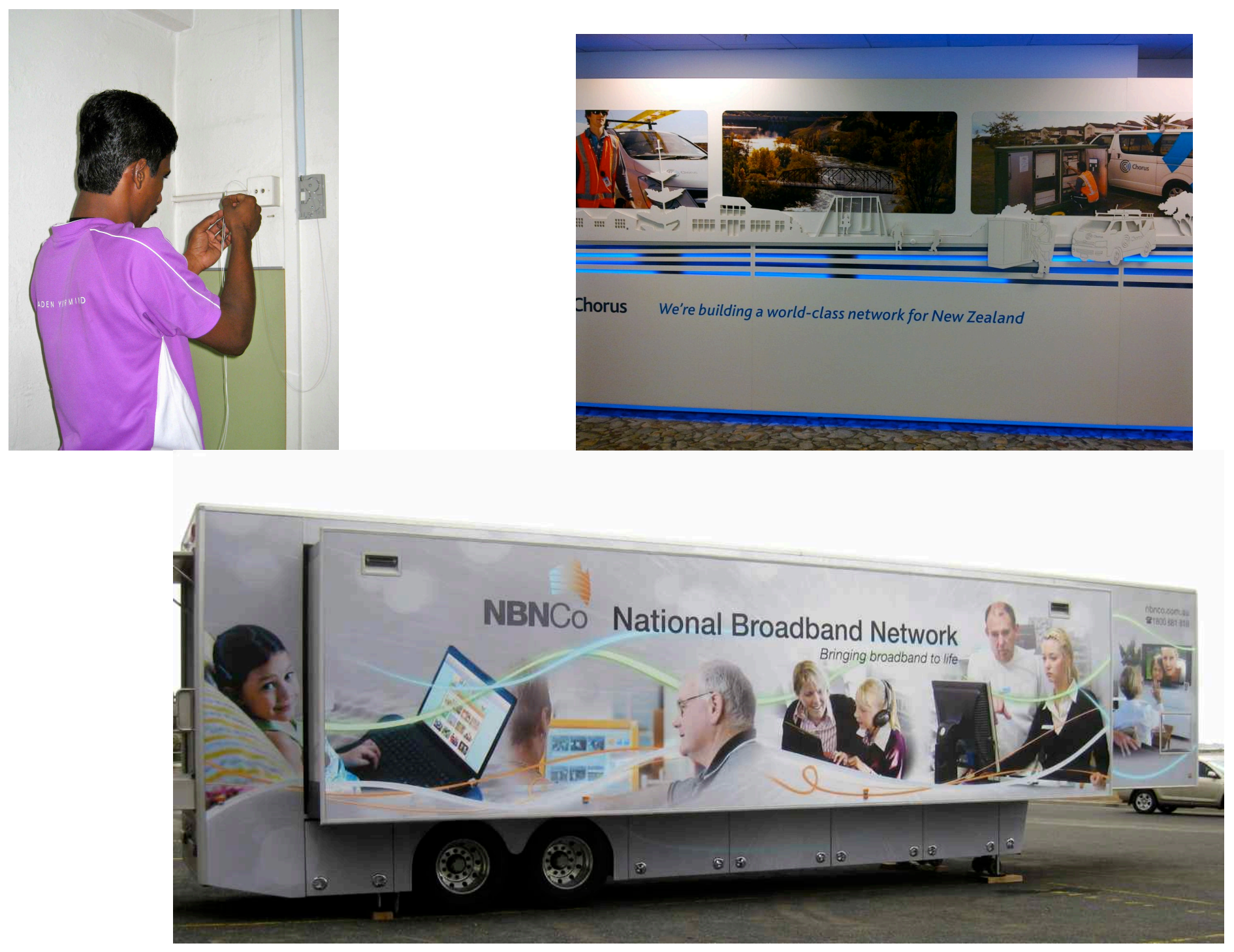


\section{Encourage digital literacy}

- Foster effective use of the internet, encourage socio-economic benefit from access to online data and services

- Individuals and businesses, especially SMEs
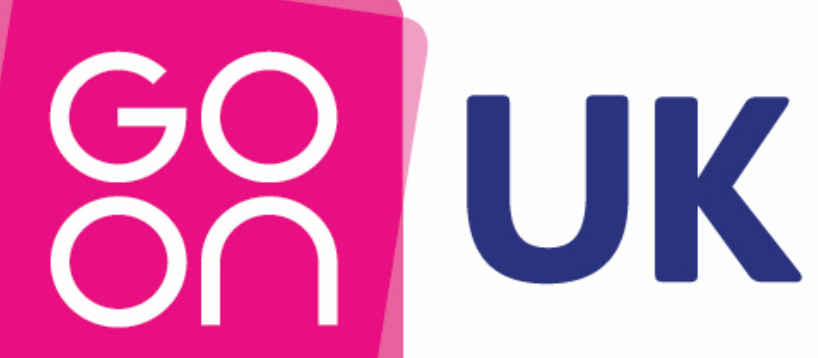


\section{Define service delivery in a digital economy}

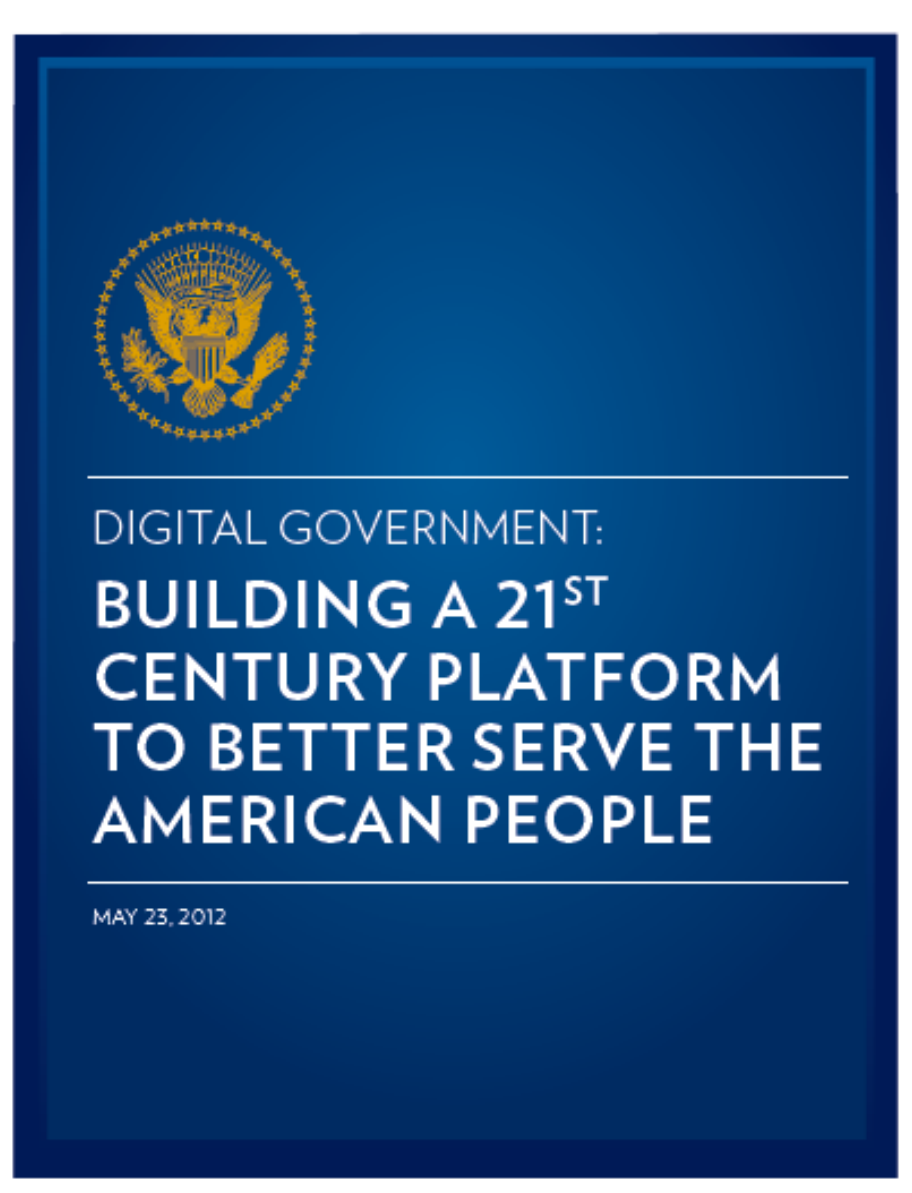

Objectives include:

"Enabling the

American people and

an increasingly

mobile workforce to

access high-quality

digital government

information and

services anywhere,

anytime, on any

device." 


\section{Government Digital Strategy}

November 2012

"Digital by default means digital services which are so straightforward and convenient that all those who can use digital services will choose to do so, while those who can't are not excluded"

- Services that are convenient to the users rather than the providers; high-quality, responsive, convenient and up-to-date.

- Average cost of a central government digital transaction can be almost 20 times lower than the cost of telephone and 50 times lower than face to face, also saves time/money for users 


\section{Canada's digital economy*}

* with a focus on citizen access to, and participation in, the knowledge economy 


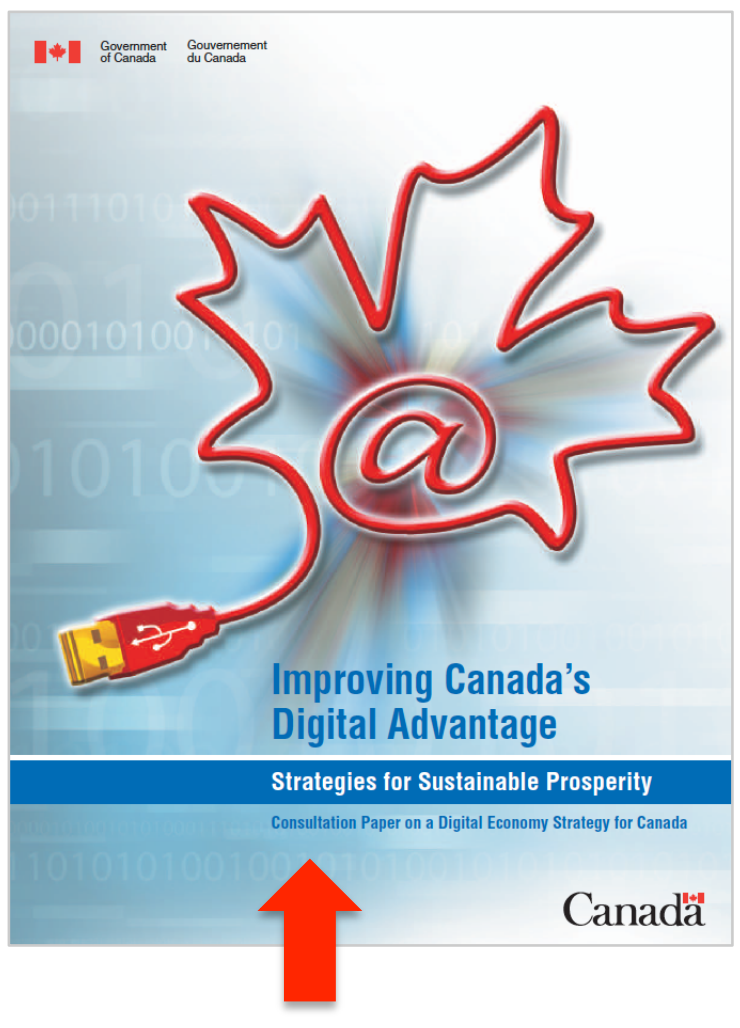

\section{Canada?}

Digital economy strategy finalized and ready for release, sources say

NEWS I THE WIRE REPORT 101/30/2014 5.01 PM EST

The federal government has finalized its long-awaited digital economy strategy and could release the policy as early as next month, sources familiar with the government's plans said.

Three people contacted by The Wire Report this month confirmed a formal digital economy plan has been

finalized after more than four years of preparation. They said the plan is ready for release, most likely by this spring, if not sooner. 


\section{eGovernment in Canada?}

"Canadians rely more on the Internet to conduct business, and they expect the government to keep pace and provide them with online information and services that meet their needs," but:

$\| \rightarrow$ "there is no government-wide service delivery strategy and that there has been no overall assessment of client needs and satisfaction since 2005" Auditor General 2013

III $\Rightarrow$ no mention of mobile in audit of access to online services 


\section{Broadband access}

- Federal funding for Community Access Program ended March 2012

- Broadband Canada 2009-2012

- "the Commission [CRTC] establishes target speeds of 5 megabits per second (Mbps) downstream and $1 \mathrm{Mbps}$ upstream. These speeds should be available to all Canadians, through a variety of technologies, by the end of 2015" 


\section{The access divide in Canada}

- As of $2012,100 \%$ of urban Canadian households can access broadband

$-94 \%$ access to speeds $\geq 5 \mathrm{Mbps}$

$-32 \%$ access to $\geq 100 \mathrm{Mbps}$ (limited choice of provider)

- $85 \%$ of rural households have access to broadband

$-\geq 5 \mathrm{Mbps}$ service only available to $20 \%$ of households with fixed wireless or satellite service 


\section{Internet use in Canada}

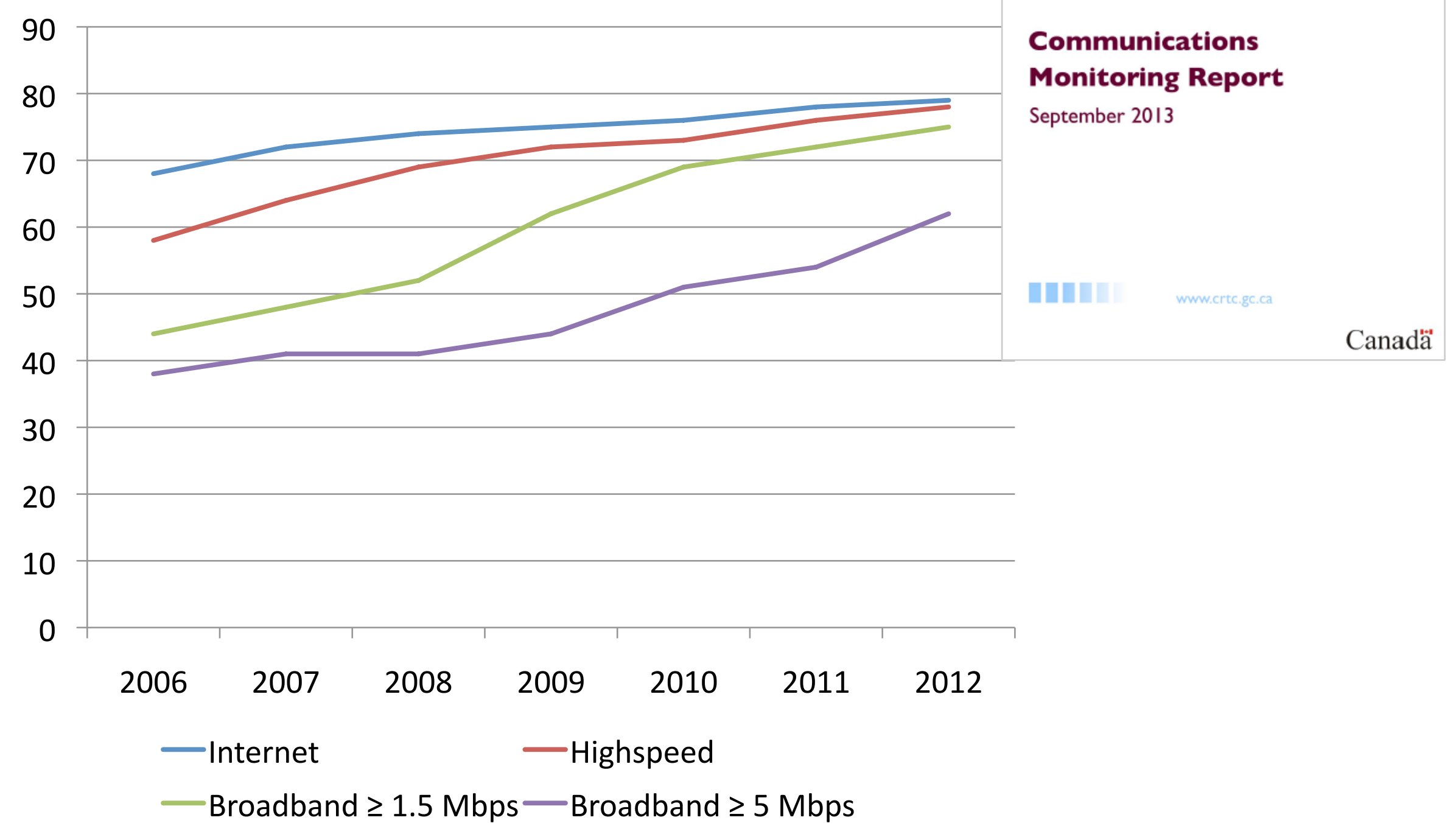




\section{Internet use by province}

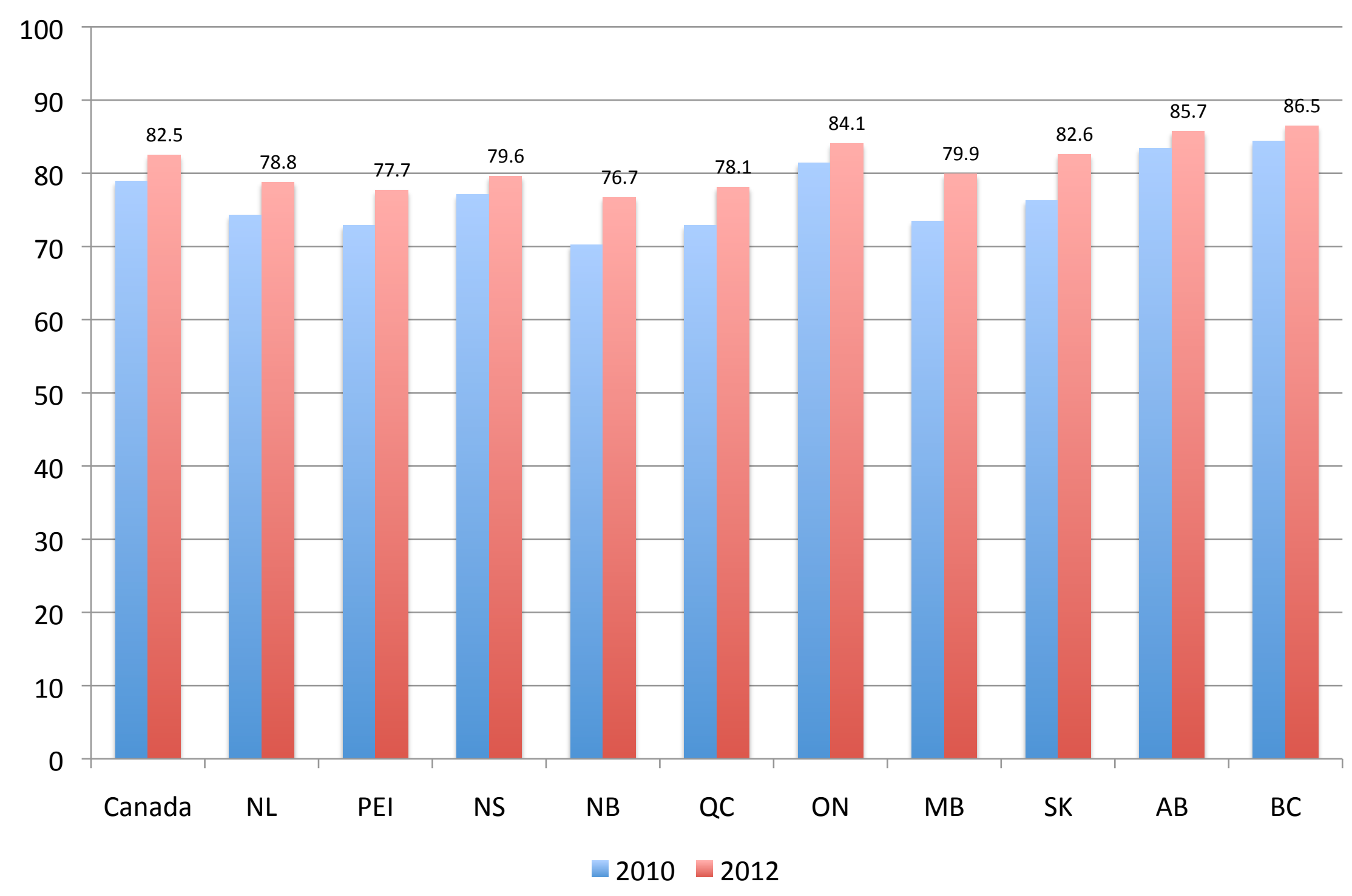

Data: Canadian Internet Use Survey, Statistics Canada 


\section{Wired broadband subscriptions}

per 100 inhabitants, by technology, June 2013, OECD data

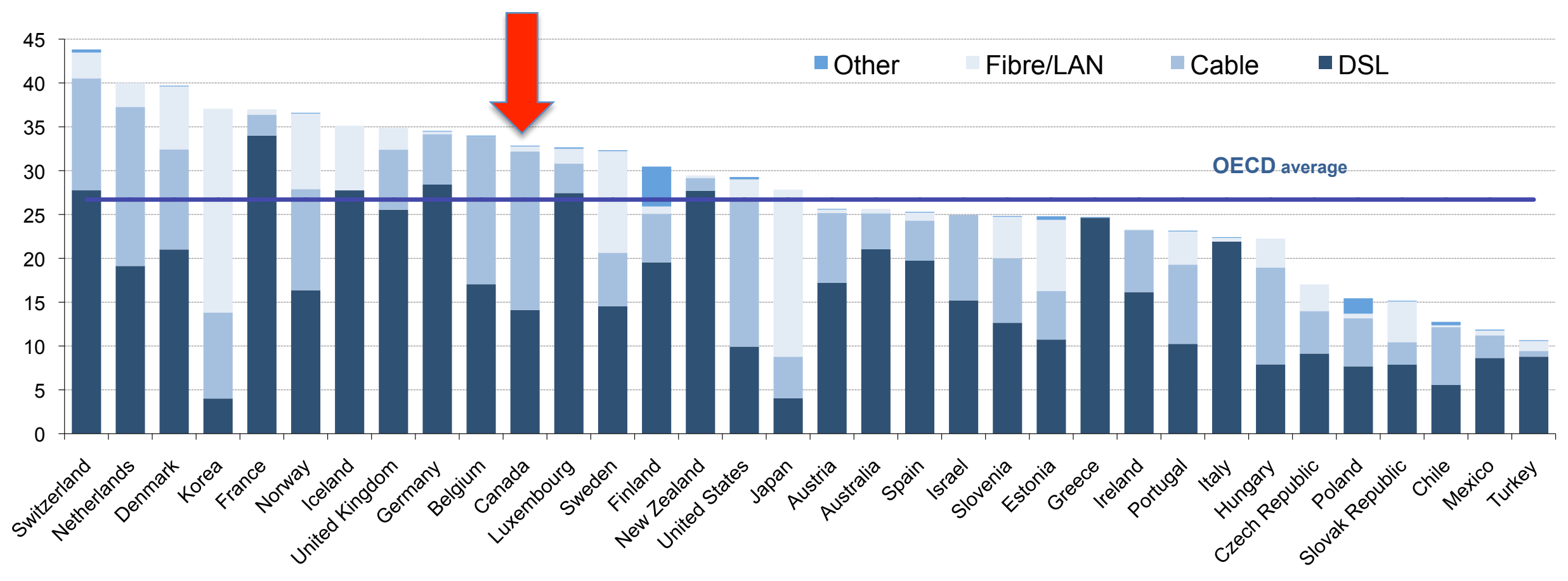




\section{$\%$ fibre connections}

Percentage of fibre connections in total broadband subscriptions, June 2013, OECD

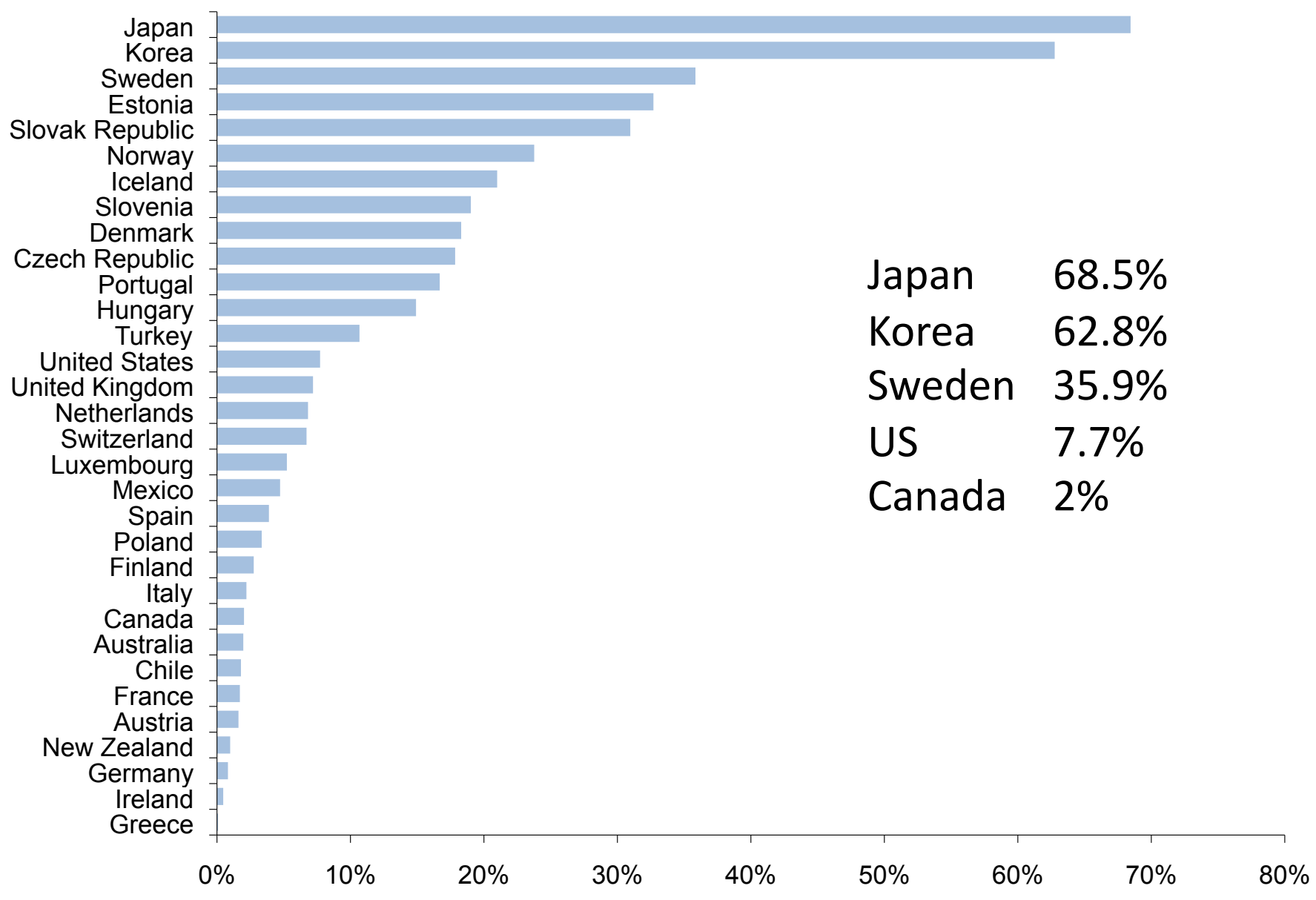




\section{Pricing comparison}

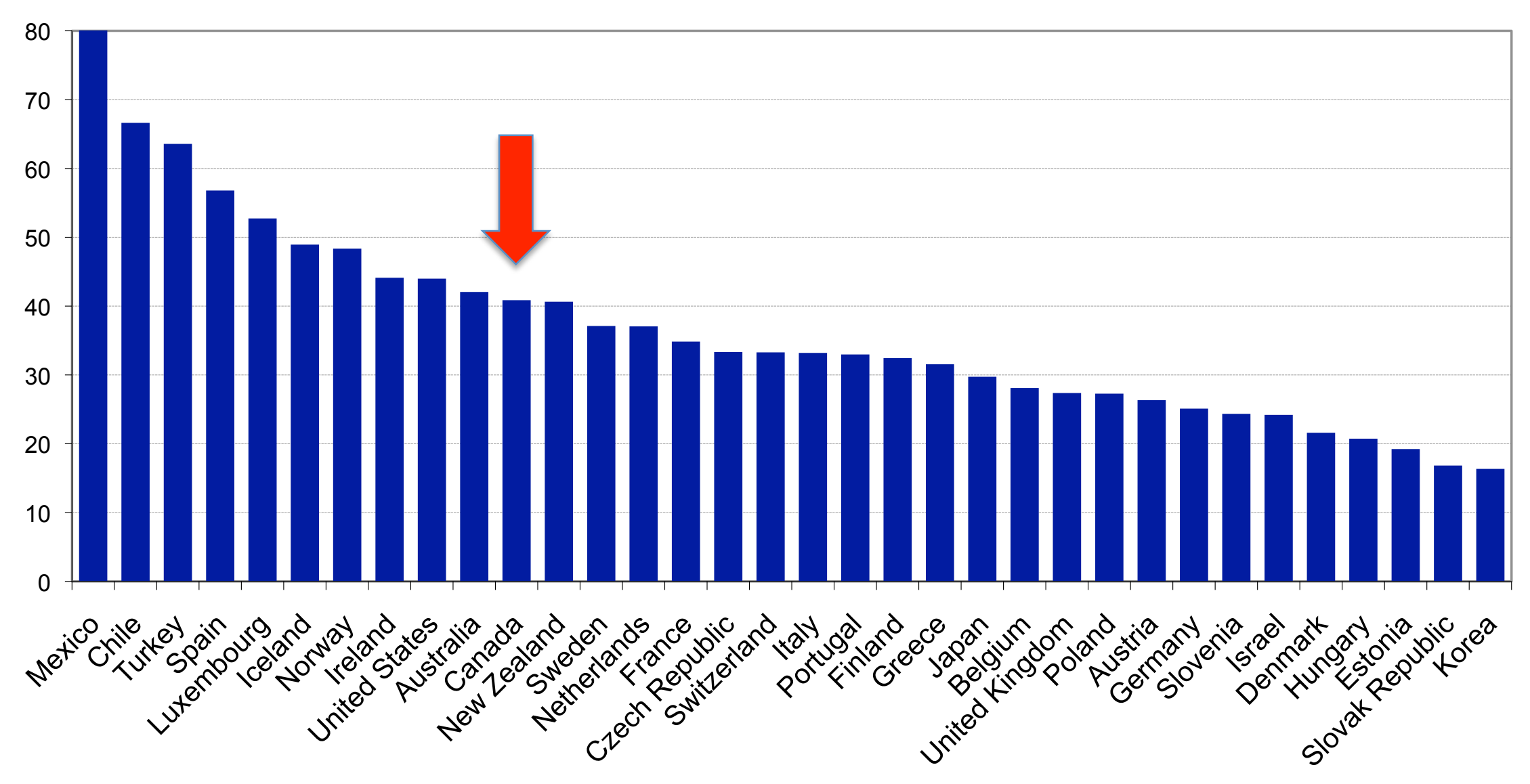

33 GB / 60 hours per month. $\geq 15$ Mbps, September 2012, OECD data 
Professor Michael Geist, commenting on a 2009 report: 'Lagging or leading? The state of Canada's broadband infrastructure'

Blog > ISP Funded Report Finds Canadian Broadband Isn't Awful

ISP Funded Report Finds Canadian Broadband Isn't Awful

Friday October 09, 2009 


\section{Improving broadband availability}




\section{DIY broadband}

- B4RN

- EC Fiber Vermont

- Can these models be scaled?
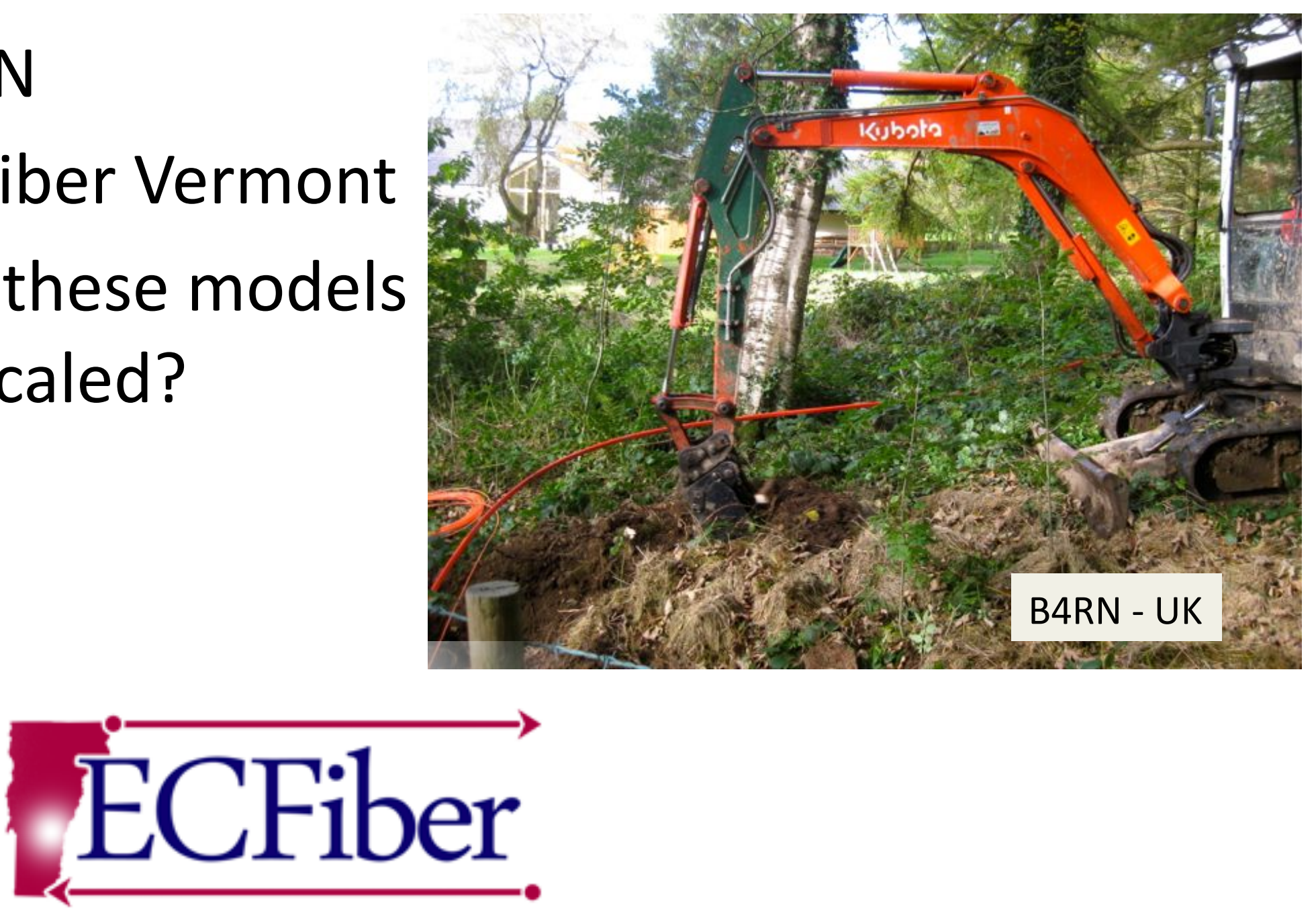


\section{Municipal networks}

- Lafayette, LA

- Chattanooga, TN

\section{EIE CITY

- St Louis Gigabit Main Street

The fiber network that permits Gig service was installed by Chattanooga's publicly owned electric power system, EPB, to support the most advanced smart grid system in the nation. The smart grid is the first killer app for Chattanooga's Gig network, but it's just one of many that the community plans to deploy as we continue to take advantage of the Gig.

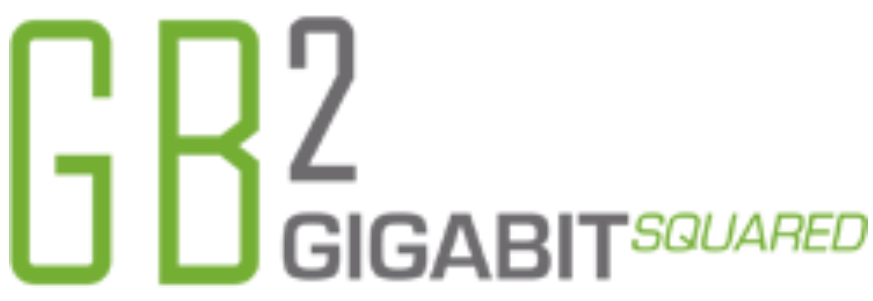




\section{Intelligent Communities}

2. trielligenic Communifity form

- Fredericton, NB

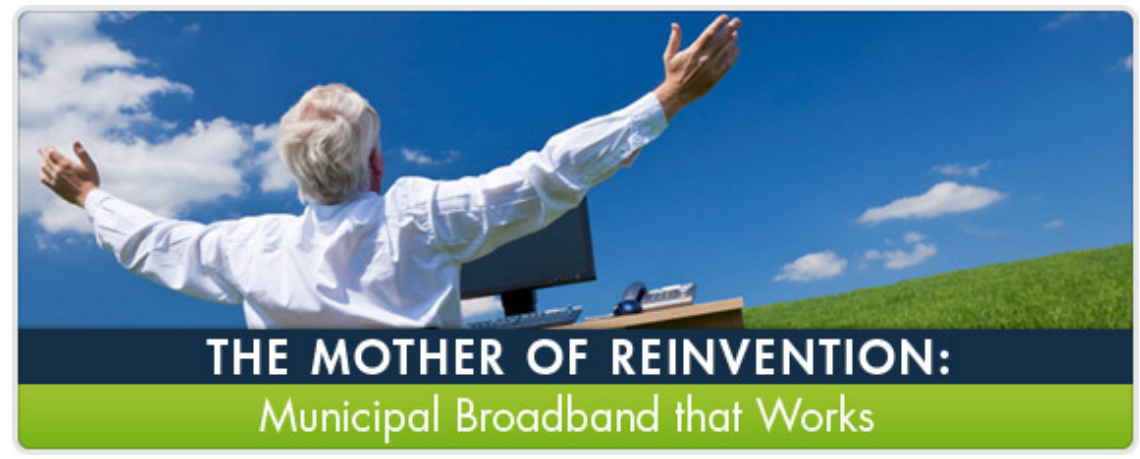

- Stratford, ON

- Broadband Connectivity, Innovation, Knowledge Workforce, Digital Inclusion, Marketing and Advocacy

A national movement to create a nation of Intelligeht Communities 


\section{Olds, Alberta Network wholly owned by the citizens of olds}

\section{(O-NET}

\section{RESIDENTIAL GIGIB IT NO DATA CAPS From $\$ 57^{*}$}

\section{Visit our store or call today: 403-556-6638}

$\$ 57$ when bundled with TV and Phone. Limited Time Offer. Conditions Apply.
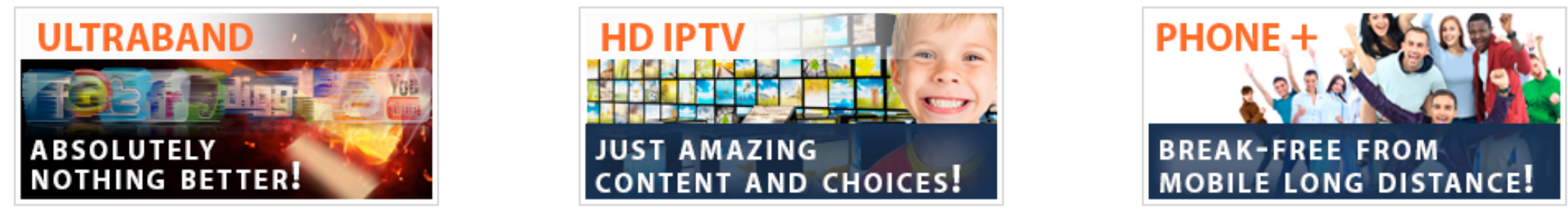


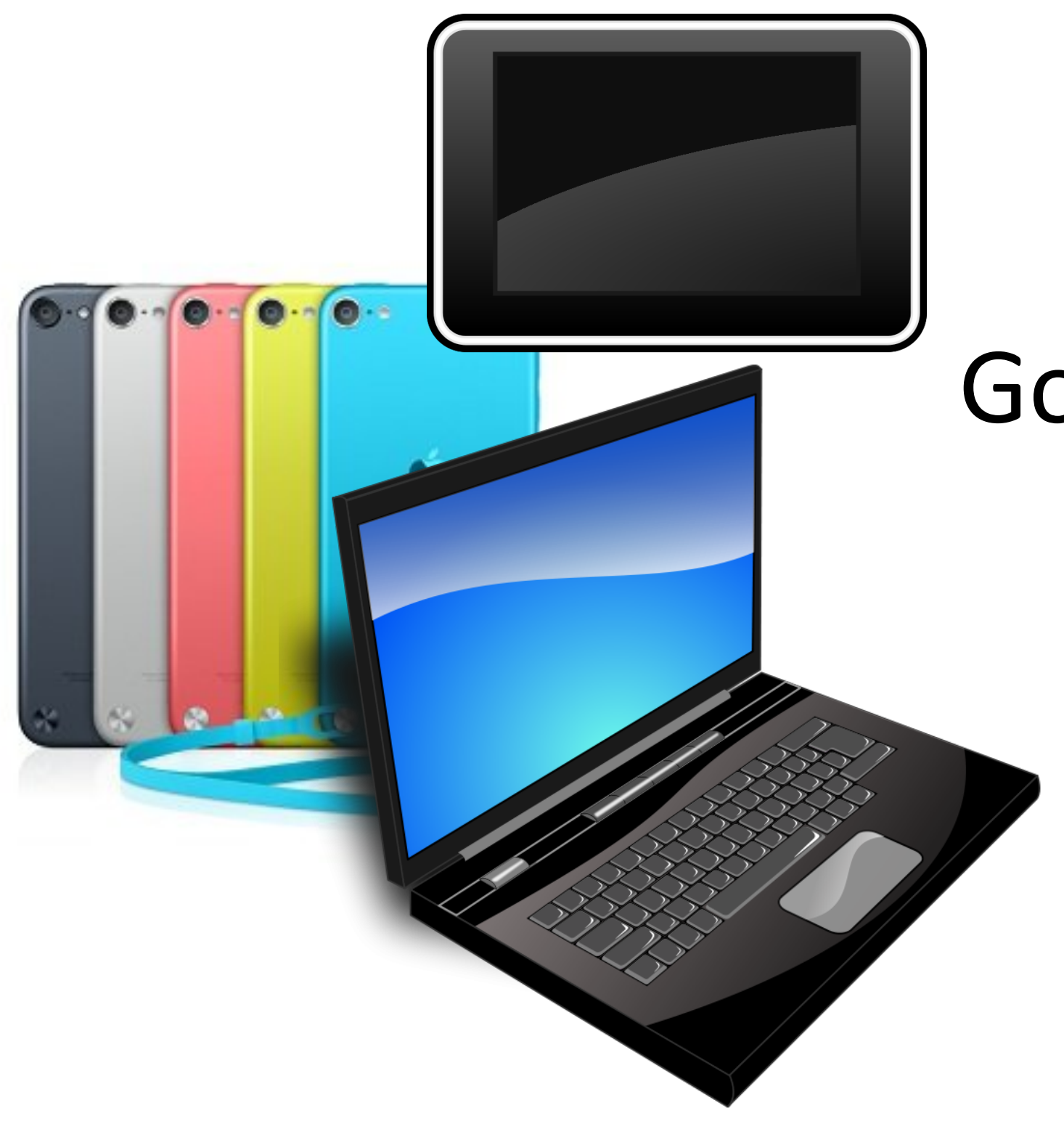




\section{What about mobile services?}

- Mobile networks cover 20\% of Canada's geographic area

- 99\% of Canadians have access to mobile phone and data service

- $72 \%$ have access to 4G/LTE (fastest available mobile data service) 


\section{Cellular stats - Canada 2012}

- $81 \%$ of Canadians subscribed to a wireless service

- $52 \%$ of wireless subscribers used smartphones, tablets and/or other advanced handheld devices

III $\approx 42 \%$ using mobile data

III $\approx 58 \%$ not (yet?) using mobile data 


\section{OECD mobile broadband subscriptions per 100 inhabitants, by technology, June 2013}

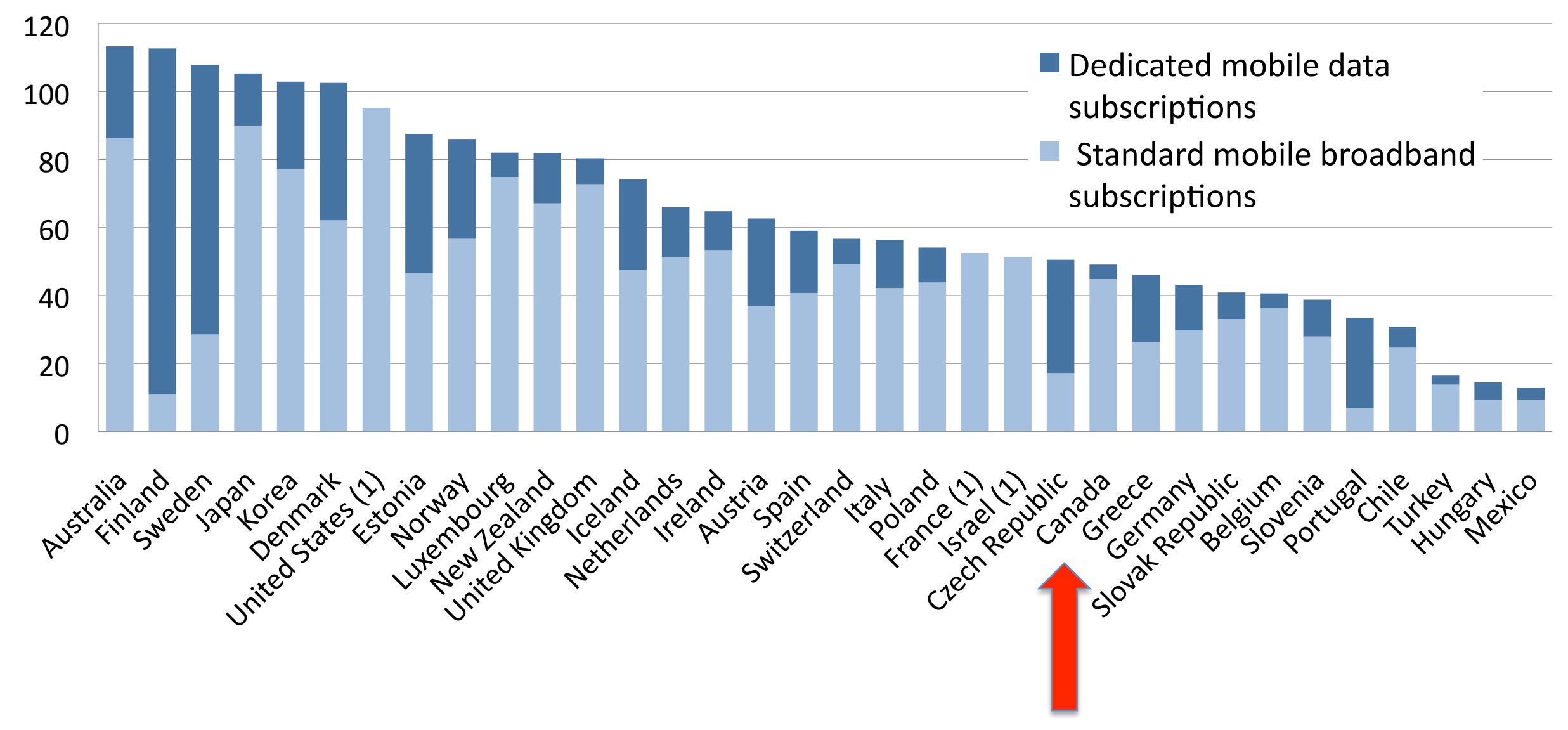

Canada 49.1, OECD average 67.8 


\section{Is the mobile market competitive?}

- Contentious debate about competition (or lack thereof) in Canada's wireless sector

- Canada $24^{\text {th }}$ in OECD in wireless broadband penetration, 109/144 in mobile phone penetration (ITU data) 


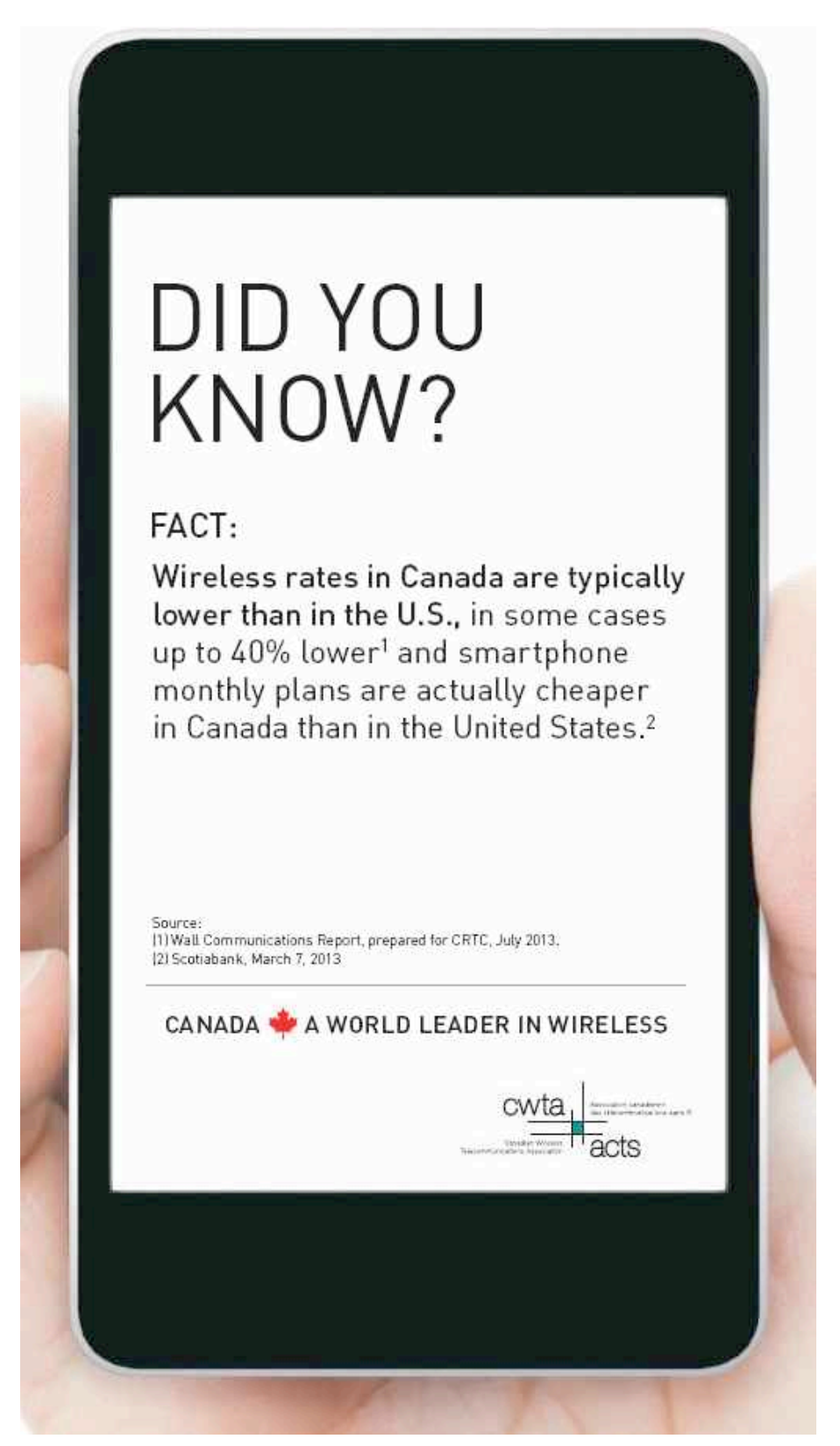




\section{OECD 100 calls +2 GB mobile basket}

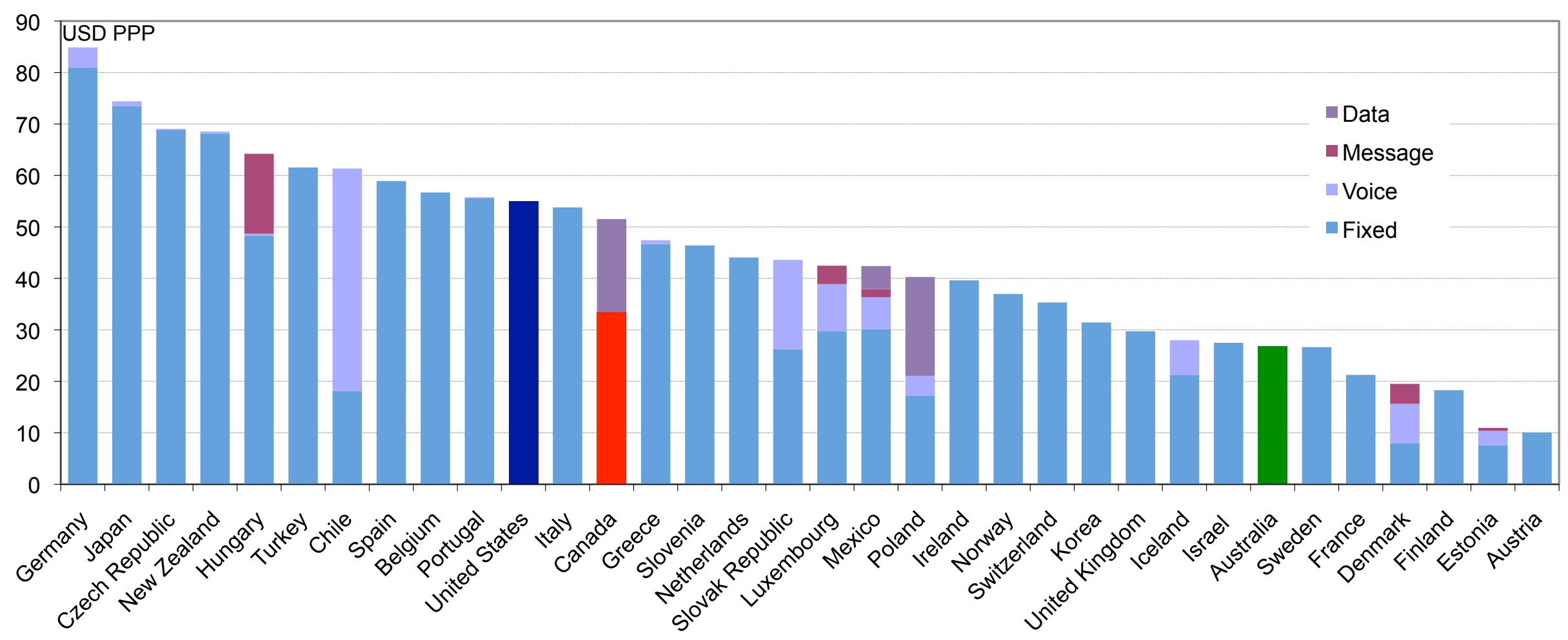

OECD Communications Outlook 2013, August 2012 data 


\section{OECD Wireless Broadband basket, Laptop $500 \mathrm{MB}$}

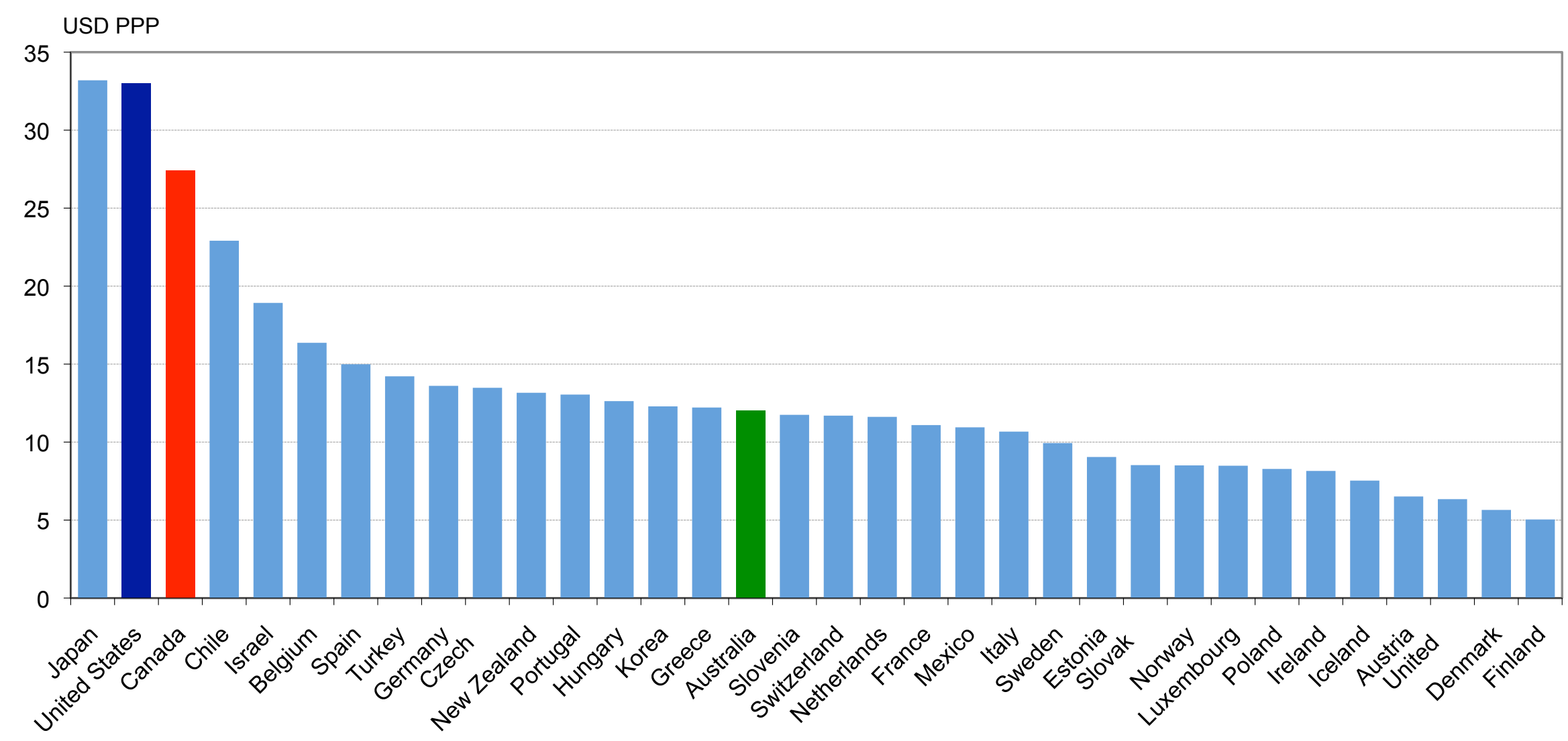

OECD Communications Outlook 2013, Sept 2012 data 


\section{OECD Wireless Broadband basket, Laptop $1 \mathrm{~GB}$}

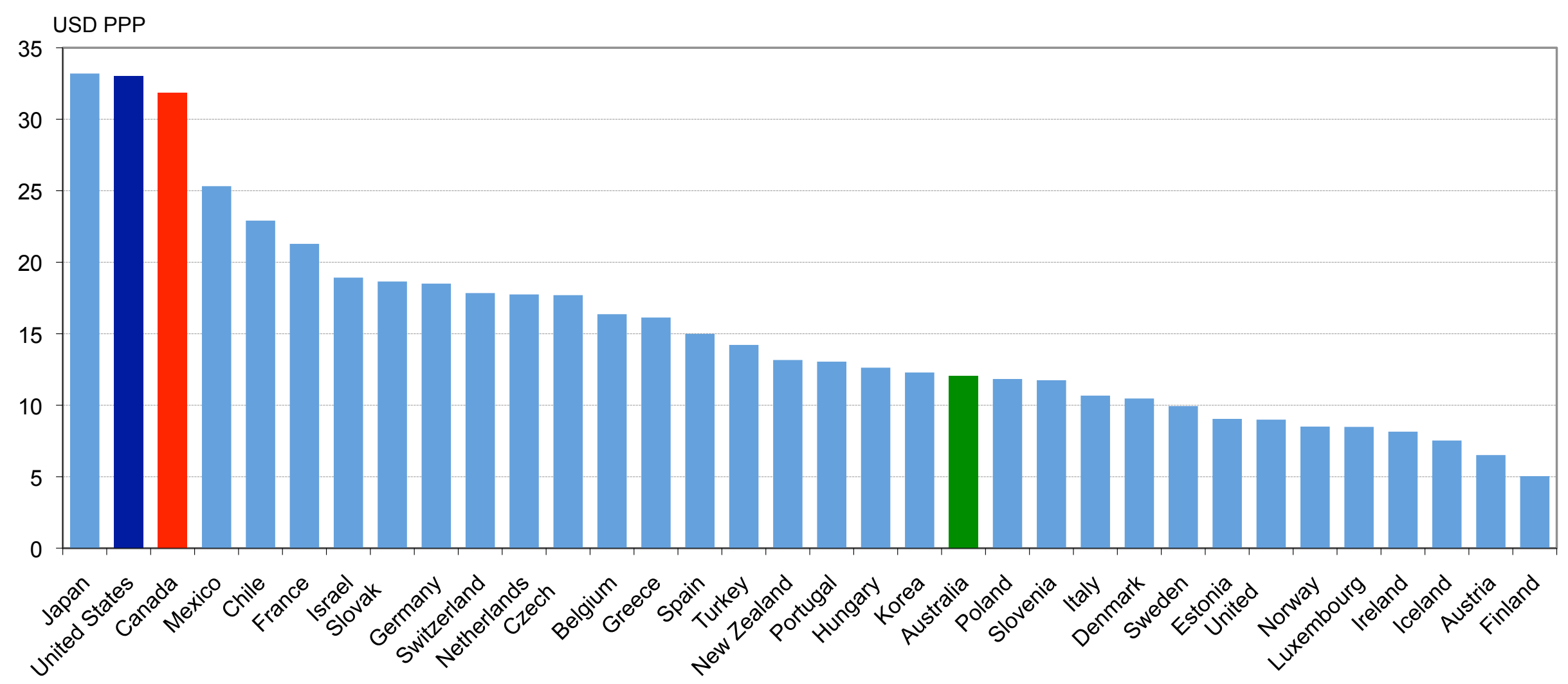

OECD Communications Outlook 2013, Sept 2012 data 


\section{Make an informed choice}

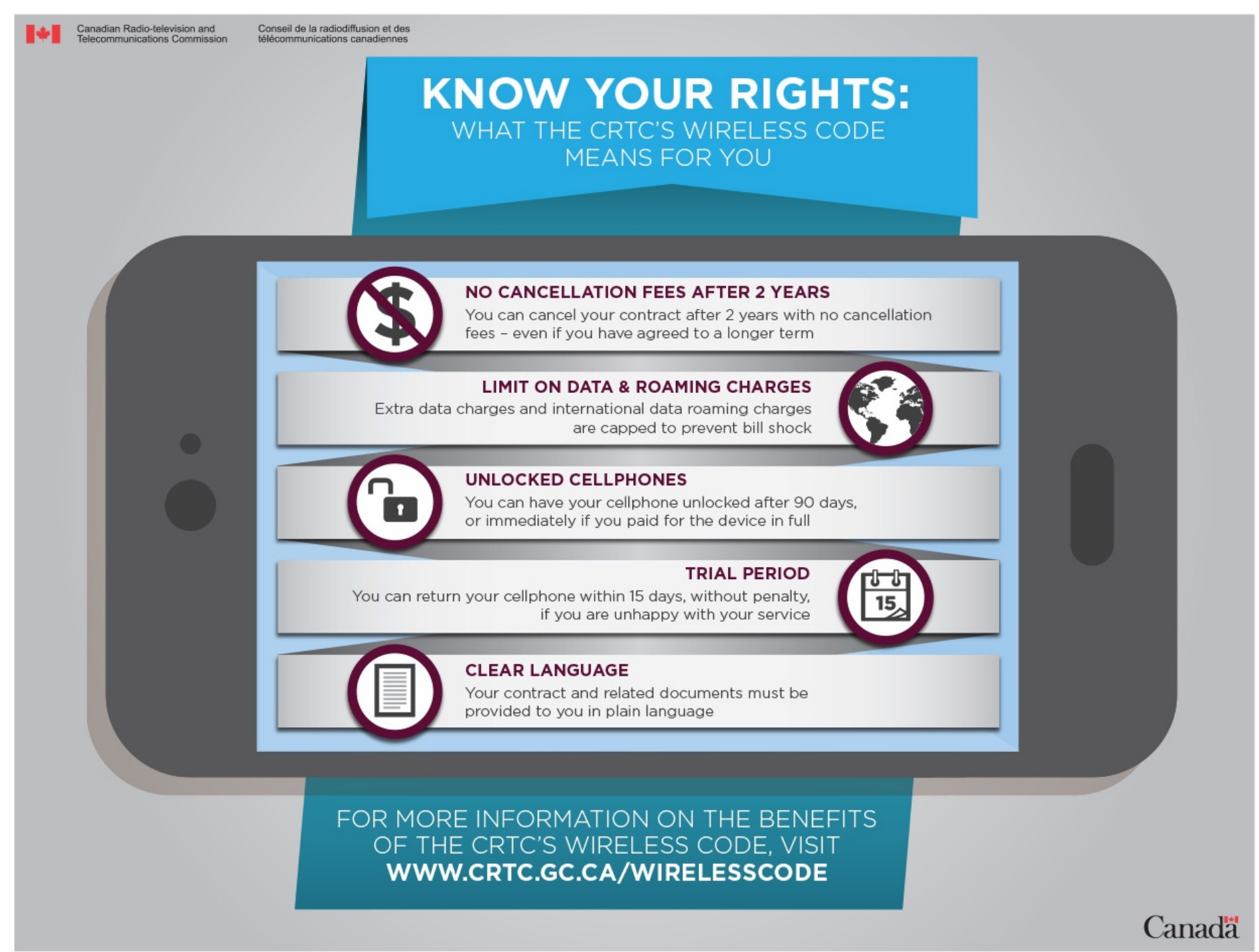




\section{What can libraries do?**}

** thoughts from a non-librarian 


\section{What about libraries?}

- Enablers of the digital economy, connecting people to knowledge

- Very important role as access provider:

- Wi-Fi, connected computers, e-readers, tablets

- Enormous impact in increasing digital literacy, ongoing activity that provides real value to communities 


\section{What do Canadians do online?}

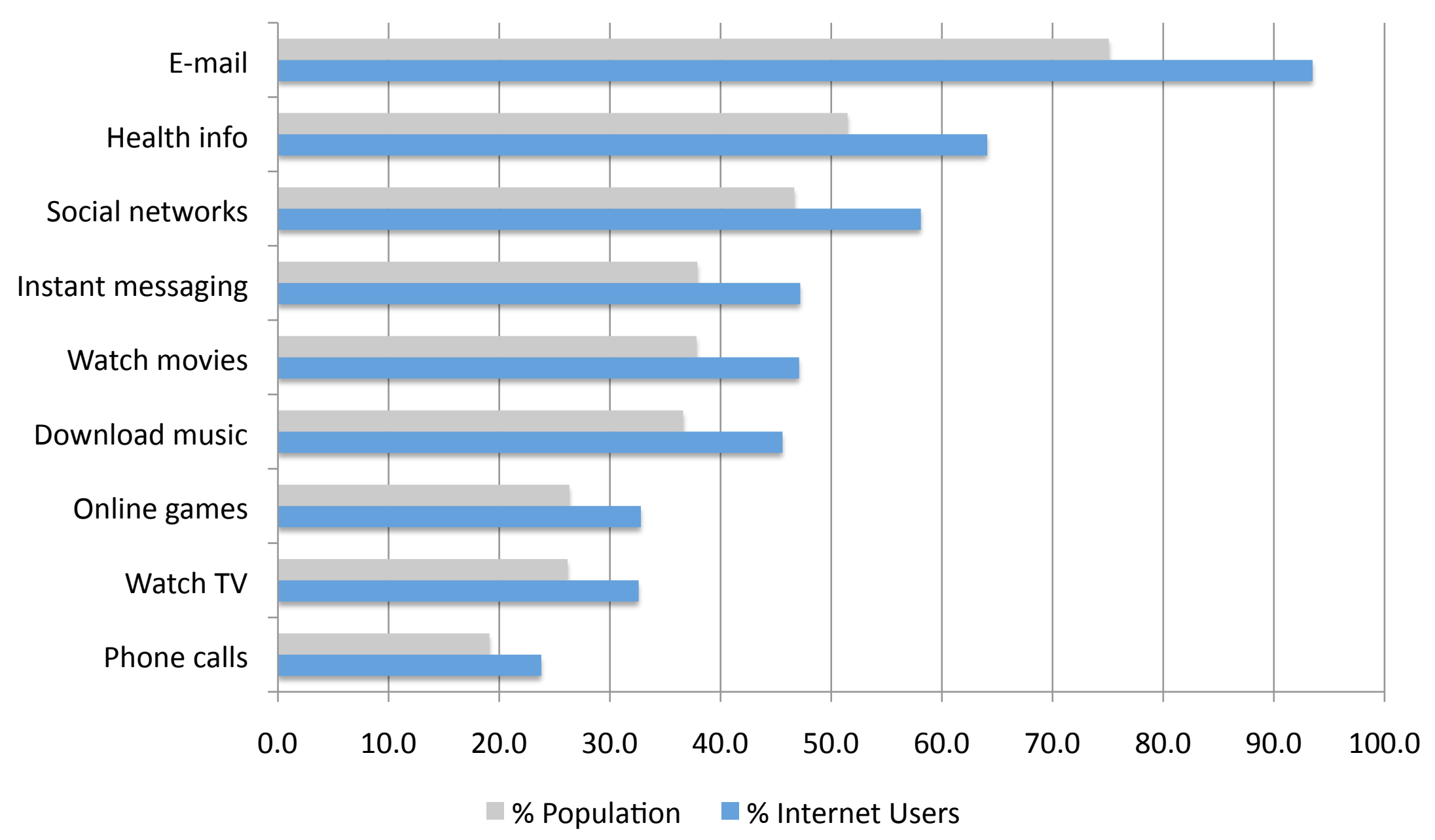




\section{Tablet ownership over time (2010-2013)}

$\%$ of American adults ages $18+$ who own a tablet computer, over time.

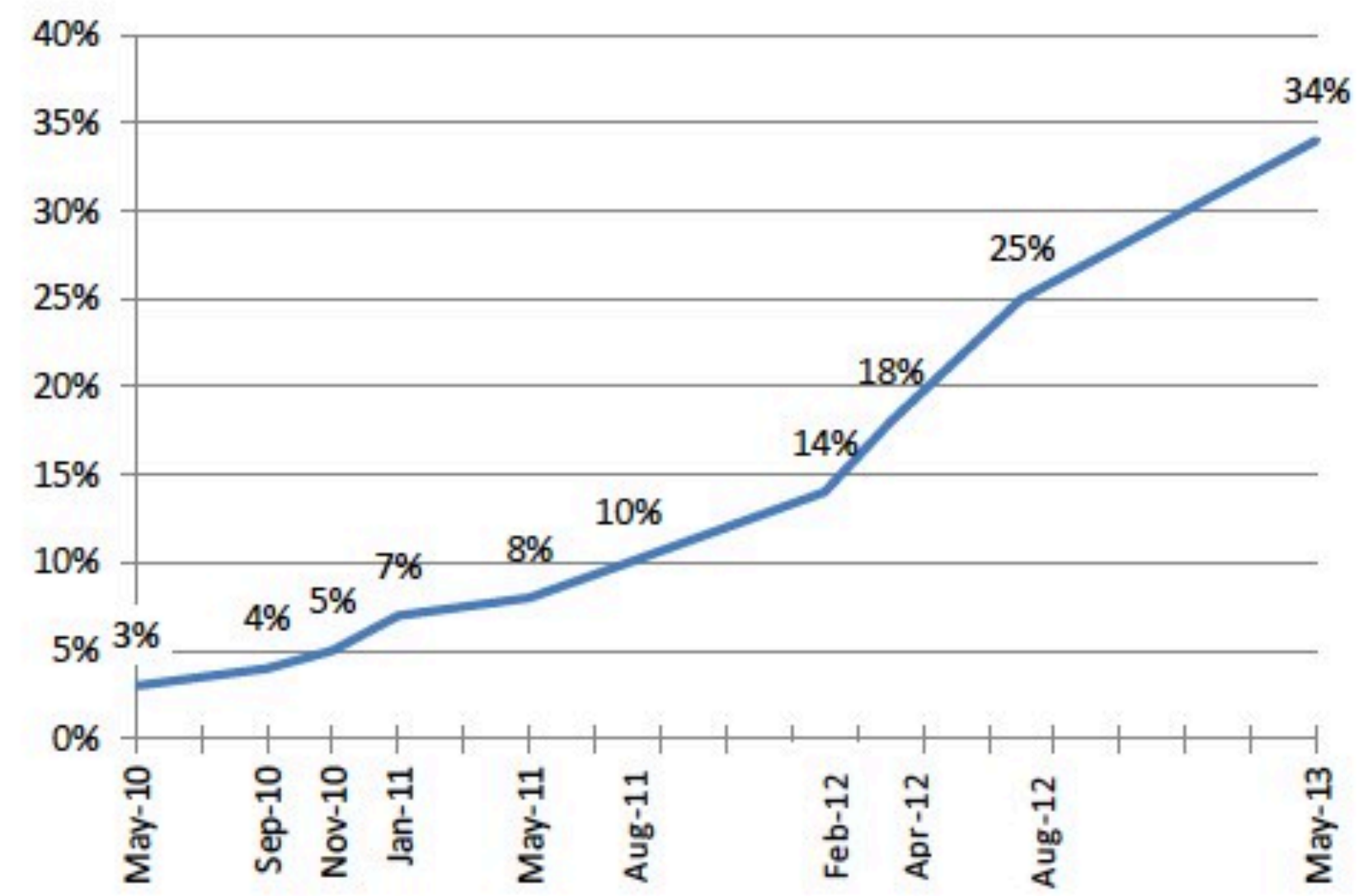

Source: Pew Research Center's Internet \& American Life Project tracking surveys, May 2010 - May 2013. May 2013 data is from the Pew Research Center's Internet \& American Life Project's April 17-May 19, 2013 Tracking Survey of 2,252 adults ages 18 and older. Interviews were conducted in English and Spanish and on landline and cell phones. The margin of error on the sample is $+/-2.3$ percentage points. 


\section{Smartphone user demographics}
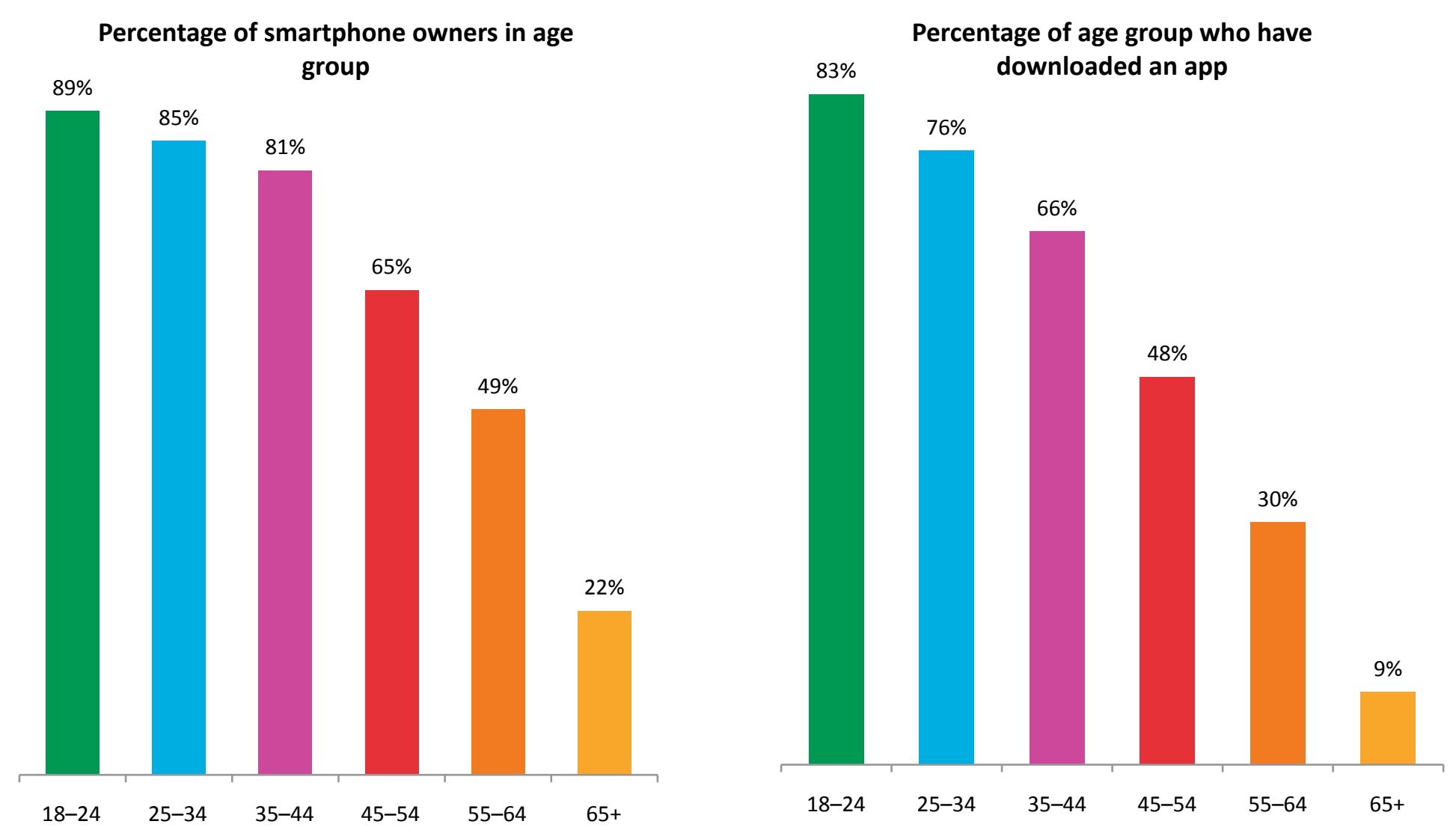

Australia, May 2013. ACMA research “Mobile apps: putting the 'smart' in smartphones 
Need for mobile literacy

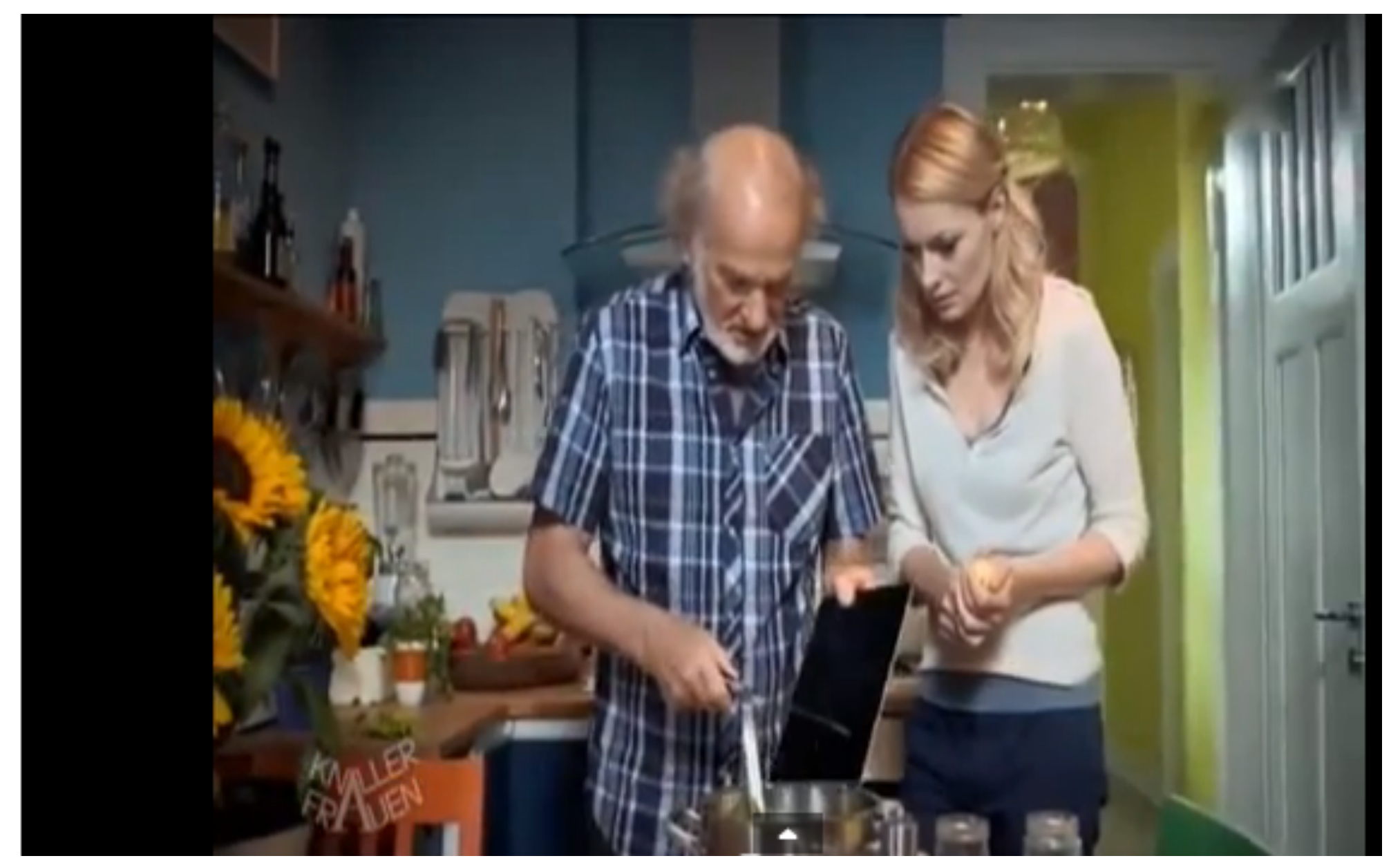




\section{and digital literacy in the home}

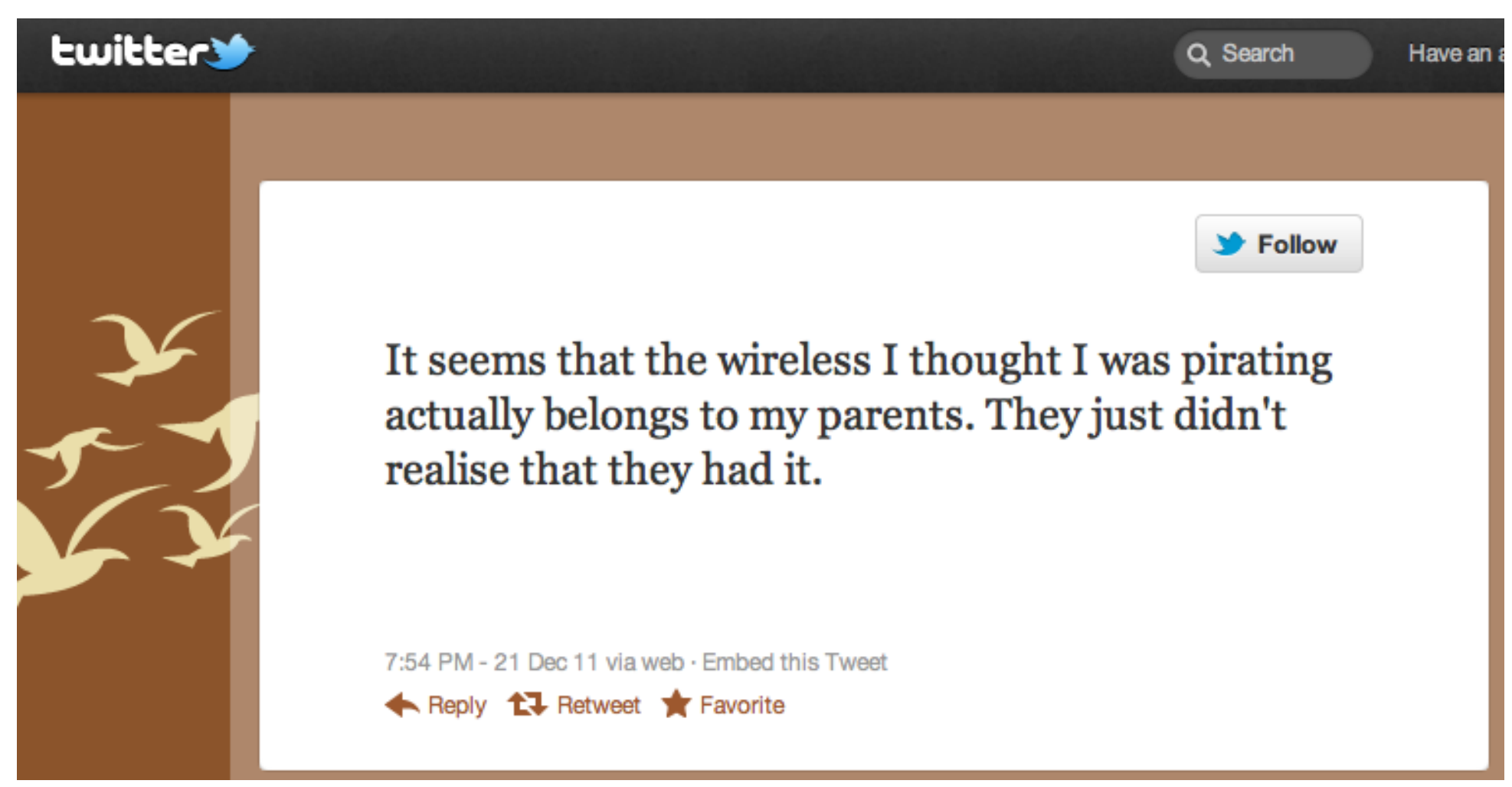


Thank you!

@catmiddleton

catherine.middleton@ryerson.ca

www.ryerson.ca/ ${ }^{c m i d d l e t}$ 
Additional data sources
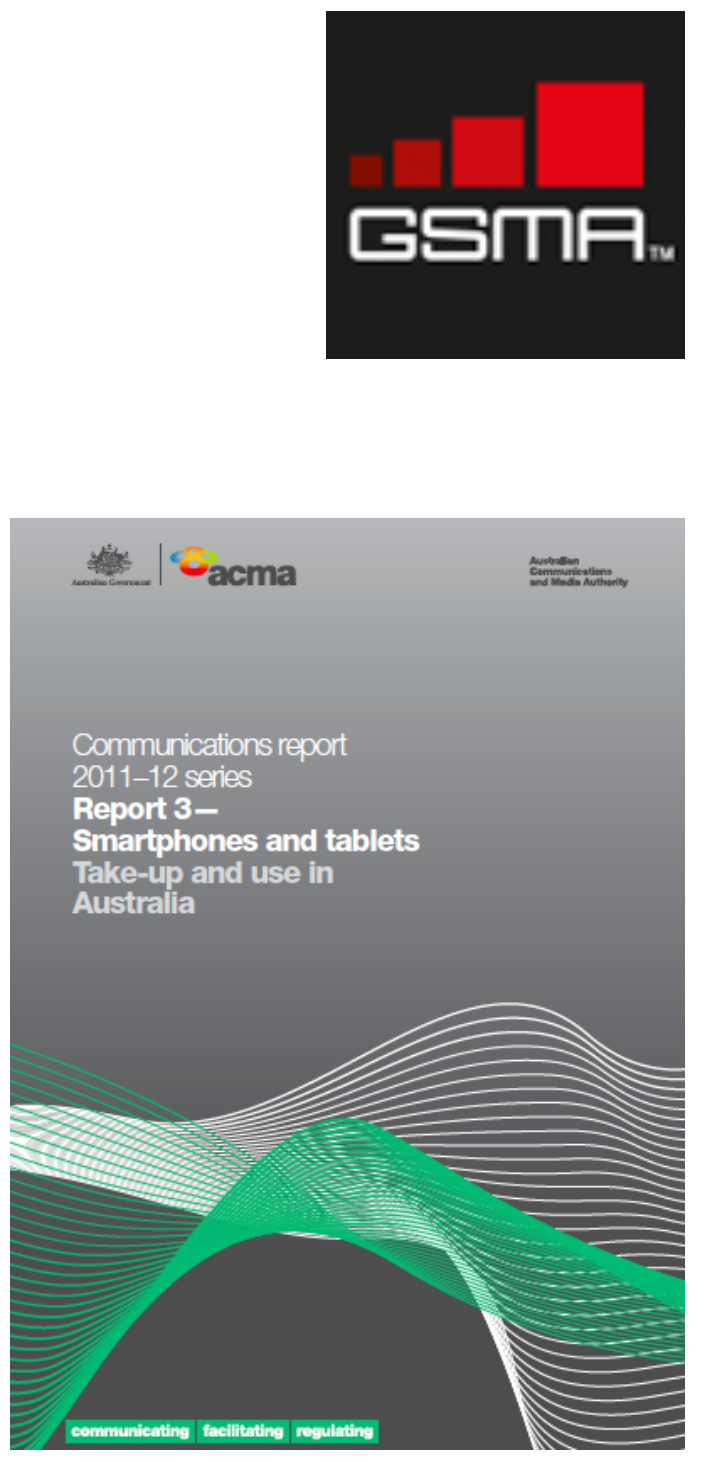

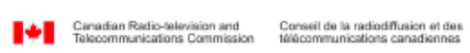

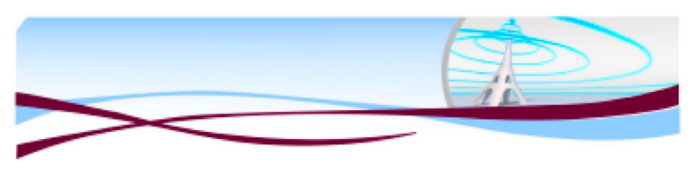

\section{Communications}

Monitoring Report

September 2013

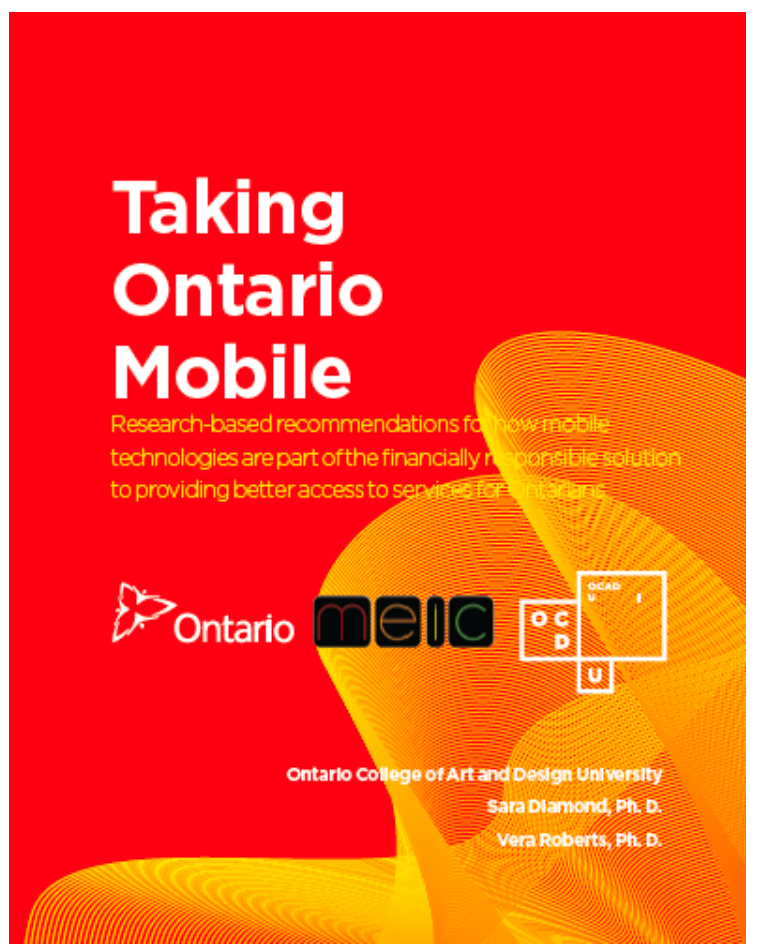

\section{Ofeom}

International Communications Market Report 


\section{References}

Slide 3

Digital Agenda for Europe: http://ec.europa.eu/digital-agenda/en (2010)

Singapore: http://www.ida.gov.sg/Infocomm-Landscape/iN2015-Masterplan; http://www.ida.gov.sg/ /media/Files/Infocomm \%20Landscape/iN2015/IDAInfographi.pdf (2006)

Department for Culture Media and Sport, \& Department for Business Innovation and Skills (2009). Digital Britain - Final Report June 2009. Kew, Richmond, Surrey: Office of Public Sector Information.

Australian Government (2013). Advancing Australia as a Digital Economy: An Update to the National Digital Economy Strategy. Canberra: Department of Broadband, Communications and the Digital Economy. (note this document is no longer available as it was the policy of the previous Australian federal government)

Federal Communications Commission (2010). Connecting America: The National Broadband Plan. Washington, DC: FCC. http:// download.broadband.gov/plan/national-broadband-plan.pdf

Slide 4

Cisco, \& International Telecommunication Union (2013). Planning for Progress: Why National Broadband Plans Matter. Geneva:

International Telecommunication Union. http://www.broadbandcommission.org/documents/reportNBP2013.pdf

Slide 5

Singapore: Infocomm Development Authority of Singapore (2013). Fact Sheet: Next Generation Nationwide Broadband Network (July 2013). https://www.ida.gov.sg/ /media/Files/Infocomm\%20Landscape/Infrastructure/Wired/

NextGenNBNFACTSHEET.pdf

Australia: www.nbnco.com.au

New Zealand: Ministry of Economic Development. Ultra-Fast Broadband Initiative. http://www.med.govt.nz/sectors-industries/ technology-communication/fast-broadband/ultra-fast-broadband-initiative

Slide 6

Go On UK: http://www.go-on.co.uk/ 
Slide 7

US Department of State (2012). Digital Government: Building a 21st Century Platform to Better Serve the American People. Washington, DC. http://www.state.gov/digitalstrategy

Slide 8

Cabinet Office (2012, updated 2013). Government Digital Strategy. United Kingdom. https://www.gov.uk/government/ publications/government-digital-strategy

Slide 10

Government of Canada (2010). Improving Canada's Digital Advantage. Strategies for Sustainable Prosperity - consultation Paper on a Digital Economy Strategy for Canada. http://publications.gc.ca/collections/collection_2010/ic/lu4-144-2010-eng.pdf

http://www.thewirereport.ca/news/2014/01/30/digital-economy-strategy-finalized-and-ready-for-release-sources-say/27797

Slide 11

Auditor General (2013). Report of the Auditor General of Canada_Fall 2013. http://www.oag-bvg.gc.ca/internet/English/ parl_oag_201311_02_e_38796.html.

Slide 12

Industry Canada (2009). Broadband Canada: Connecting Rural Canadians. http://www.ic.gc.ca/eic/site/719.nsf/eng/home

Canadian Radio-Television and Telecommunications Commission (2011). Telecom Regulatory Policy CRTC 2011-291: Obligation to Serve and Other Matters. http://www.crtc.gc.ca/eng/archive/2011/2011-291.htm

Slide 13

Canadian Radio-Television and Telecommunications Commission (2013). Communications Monitoring Report. http:// www.crtc.gc.ca/eng/publications/reports/PolicyMonitoring/2013/cmr.htm

Slide 14

Canadian Radio-Television and Telecommunications Commission (2007). CRTC Telecommunications Monitoring Report: Status of Competition in Canadian Telecommunications Markets - Deployment/Accessibility of Advanced Telecommunications Infrastructure and Services

Canadian Radio-Television and Telecommunications Commission (2008, 2009, 2010, 2011, 2012, 2013). Communications Monitoring Report. 
Slide 15

Statistics Canada Canadian Internet Use Survey: http://www.statcan.gc.ca/daily-quotidien/131126/dq131126d-eng.htm

Slide 16

http://www.oecd.org/sti/broadband/1d-OECD-WiredWirelessBB-2013-06.xls

Slide 17

http://www.oecd.org/sti/broadband/11-PctFibreToTotalBroadband-2013-06.xls

Slide 18

http://dx.doi.org/10.1787/888932799722

Slide 19

Mark H. Goldberg \& Associates Inc., \& Giganomics Consulting Inc. (2009). Lagging or Leading? The State of Canada's Broadband Infrastructure. Toronto. http://www.gstconferences.com/public/project/LagOrLead.pdf

http://www.michaelgeist.ca/content/view/4443/125

Slide 21

http://b4rn.org.uk

http://www.ecfiber.net/

Slide 22

http://www.thegigcity.com/about/

Lafayette, LA: http://www.ftthcouncil.org/p/bl/et/blogid=1\&blogaid=215

Gigabit Squared: http://gigabitsquared.com/, e.g. Chicago: http://gigabitsquared.com/my-kind-of-town-chicago-is-the-firstrecipent-of-gb2s-gigabit-neighborhood-gateway-program/

http://loopdatarail.org/ 
Slide 23

http://www.fred-ezone.ca/

http://stratfordsmartcity.ca/

http://icanada.nu/about-i-canada-alliance/the-i-canada-vision/

Slide 24

http://www.o-net.ca/manage/residential

Slide 26

Canadian Radio-Television and Telecommunications Commission (2013). Communications Monitoring Report. http:// www.crtc.gc.ca/eng/publications/reports/PolicyMonitoring/2013/cmr.htm

Slide 27

CRTC 2013, p. ii. For breakdown of mobile data use, see Table 5.5.9, p. 165

Slide 28

OECD Fixed and wireless broadband subscriptions per 100 inhabitants (June 2013) http://www.oecd.org/sti/broadband/ oecdbroadbandportal.htm Graph redrawn to include only mobile broadband.

Slide 29

Wireless broadband data: OECD (2014). OECD Terrestrial Mobile Wireless Broadband Subscriptions Per 100 Inhabitants, by Technology, June 2013. http://www.oecd.org/sti/broadband/1d-OECD-WiredWirelessBB-2012-6.xls

Mobile phone penetration data: International Telecommunication Union (2012). World Telecommunication/ICT Indicators Database 2012 (16th Edition). Geneva: ITU. http://www.itu.int/ITU-D/ict/publications/world/world.html, reported in BilbaoOsorio, B., Dutta, S., \& Lanvin, B. (2013). The Global Information Technology Report 2013: Growth and Jobs in a Hyperconnected World. Geneva: World Economic Forum and INSEAD. http://reports.weforum.org/global-informationtechnology-report-2013/ 
Slide 30

CWTA advertisement in Saturday Globe and Mail, July 6, 2013 p. A7

Wall Communications Inc. (2013). Price Comparisons of Wireline, Wireless and Internet Services in Canada and with Foreign Jurisdictions - 2013 Update. Prepared for the Canadian Radio-television and Telecommunications Commission and Industry Canada. http://crtc.gc.ca/eng/publications/reports/rp130422.htm.

Slide 31

Figure 7-24, Organisation for Economic Co-operation and Development (2013). OECD Communications Outlook. Paris: OECD.

Slide 32

Figure 7-25, Organisation for Economic Co-operation and Development (2013). OECD Communications Outlook. Paris: OECD.

Slide 33

Figure 7-26, Organisation for Economic Co-operation and Development (2013). OECD Communications Outlook. Paris: OECD.

Slide 34

http://www.crtc.gc.ca/eng/info_sht/t16.htm

Slide 37

http://www.statcan.gc.ca/daily-quotidien/110525/dq110525b-eng.htm

Slide 38

http://www.pewinternet.org/Reports/2013/Tablet-Ownership-2013/Findings.aspx

Slide 39

http://www.acma.gov.au/theACMA/engage-blogs/engage-blogs/Research/Reseach-Snapshots/Mobile-apps-putting-the-smart-insmartphones 
Slide 40

https://www.youtube.com/watch?v=1hOVNiLC6xM

Slide 43

GSMA: https://gsmaintelligence.com/analysis/2013/12/2013-the-year-in-research/410/

Canadian Radio-television and Telecommunications Commission (2013). Communications Monitoring Report. Ottawa: Canadian Radio-television and Telecommunications Commission. http://www.crtc.gc.ca/eng/publications/reports/policyMonitoring/ 2013/cmr2013.pdf

Australian Communications and Media Authority (2013). Communications Report 2011-12 Series. Report 3 - Smartphones and Tablets: Take-up and Use in Australia. Melbourne: Commonwealth of Australia. http://www.acma.gov.au/theACMA/Library/ researchacma/Digital-society-research/communications-report-201112-library-landing-page

http://www.mobileinnovationreport.ca/

Ofcom (2013). International Communications Market Report 2013. London: Ofcom. http://stakeholders.ofcom.org.uk/marketdata-research/market-data/communications-market-reports/cmr13/international 